\title{
PENGARUH PENAMBAHAN PUPUK MIKRO DAN BEBERAPA GENOTIPE SORGUM (Sorghum bicolor (L.) Moench) TERHADAP INTENSITAS PENYAKIT ANTRAKNOSA (Colletotrichum sp.) DI LAHAN PETANI TANJUNG BINTANG LAMPUNG SELATAN
}

\author{
THE EFFECT OF MICRO FERTILIZER ADDITION AND SOME GENOTYPES \\ OF SORGUM (Sorghum bicolor (L.) Moench) ON ANTRACNOSA DISEASE \\ INTENSITY (Colletotrichum sp.) IN TANJUNG BINTANG SOUTHLAMPUNG
}

\author{
Farastika Unjunan Muli*, Efri, M. Syamsoel Hadi dan Radix Suharjo \\ Jurusan Agroteknologi Fakultas Pertanian Universitas Lampung \\ JL. Prof. Dr. Soemantri Brojonegoro, No. 1 Bandar Lampung 35145 \\ *Email:farastikaunjunan11@gmail.com
}

\begin{abstract}
One of the diseases that often found in sorghum plants is anthracnose disease caused by Colletotrichum $s p$. The purposed of this study was to determine the effect of adding micro fertilizer and the use of several sorghum genotypes on the intensity of anthracnose disease. The study was conducted in Sukanegara, Tanjung Bintang, South Lampung in April 2017 - February 2018 and at the Laboratory of Plant Diseases and Pests, Faculty of Agriculture, University of Lampung. The treatments were arranged using a randomized block design in a split plot design (3 times replications), the main plot was micro nutrients (with micro addition and without micro addition) and 15 subgroups of sorghum genotypes (Numbu, Samurai 1, GH3, UPCA, GH4, P / I WHP, GH6, Super 2, GH13, P / F 51-93-C, Super 1, GH5, Mandau, GH7, and Talaga Bodas). The results showed that the addition of "ZincMicro" micro fertilizers to sorghum plants did not affect the intensity of anthracnose disease, however there were differences in the intensity of anthracnose diseases between sorghum genotypes. Numbu Genotype, GH 3, and GH 13 were relatively more resistant to anthracnose disease than the other genotypes.
\end{abstract}

Keywords: Anthracnose, genotipe, mikro fertilizer, sorghum.

\begin{abstract}
ABSTRAK
Salah satu penyakit yang sering ditemukan pada tanaman sorgum adalah penyakit antraknosa yang disebabkan oleh Colletotrichum sp. Tujuan dari penelitian ini adalah untuk mengetahui pengaruh penambahan pupuk mikro serta penggunaan beberapa genotipe sorgum terhadap intensitas penyakit antraknosa. Penelitian dilakukan di Desa Sukanegara, Kecamatan Tanjung Bintang, Lampung Selatan pada April 2017 - Februari 2018 dan di Laboratorium Hama dan Penyakit Tanaman Fakultas Pertanian Universitas Lampung. Perlakuan disusun menggunakan rancangan acak kelompok dalam rancangan petak terbagi (Split Plot Design) 3 kali ulangan, petak utama hara mikro (dengan penambahan mikro dan tanpa penambahan mikro) dan anak petak 15 genotipe
\end{abstract}


sorgum (Numbu, Samurai 1, GH3, UPCA, GH4, P/I WHP, GH6, Super 2, GH13, P/F 51-93-C, Super 1, GH5, Mandau, GH7, dan Talaga Bodas). Hasil penelitian menunjukkan bahwa penambahan pupuk mikro "ZincMicro" pada tanaman sorgum tidak berpengaruh terhadap intensitas penyakit antraknosa, namun demikian terdapat perbedaan intensitas penyakit antraknosa di antara genotipe sorgum. Genotipe Numbu, GH 3, dan GH 13 relatif lebih tahan terhadap penyakit antraknosa dibandingkan genotipe yang lainnya.

Kata Kunci : Antraknosa, genotipe, hara mikro, sorgum.

\section{PENDAHULUAN}

Salah satu contoh tanaman serealia yang dapat dimanfaatkan untuk menunjang pengembangan diversifikasi pangan adalah tanaman sorgum. Sorgum mempunyai prospek yang sangat baik dikembangkan di Indonesia, karena didukung oleh kondisi agroekologis dan ketersediaan lahan yang cukup luas.

Sorgum memiliki beberapa keunggulan seperti budidaya yang mudah, umur tanaman pendek (100110 hari), dan mempunyai manfaat yang sangat luas antara lain sebagai pakan ternak, bahan baku industri makanan dan minuman, bahan baku untuk media jamur merang, industri alkohol, bahan baku etanol dan sebagainya. Menurut Suarni (2004), sorgum merupakan serealia sumber karbohidrat, dengan nilai gizi sekitar $83 \%$ karbohidrat, 3,50\% lemak, dan 10\% protein (basis kering).

Usaha budidaya tanaman sorgum terdapat beberapa hambatan, diantaranya adalah gangguan hama dan penyakit. Salah satu penyakit utama yang sering ditemukan pada tanaman sorgum adalah penyakit antraknosa disebabkan oleh Colletotrichum sp. Penyakit antaknosa pertama kali ditemukan di Italia pada tahun 1852 pada pertanaman jagung, sedang di Amerika Serikat pada tahun 1855, dan di Texas pada tahun 1912 (Frederiksen, 1986). Penyakit antraknosa berkembang baik pada tempat-tempat yang mempunyai kondisi panas dan lembab. Kehilangan hasil akibat penyakit ini bisa mencapai 50\% tetapi hal ini tergantung kapan tanaman terinfeksi.

Untuk menunjang pertumbuhan tanaman sorgum yang optimal serta tanaman dapat tahan terhadap hama dan penyakit, maka diperlukan ketersediaan hara yang mencukupi. Unsur hara yang mencukupi tersebut terbagi menjadi dua yaitu hara makro dan mikro. Salah satu contoh unsur hara mikro yang dapat membuat tanaman menjadi tahan terhadap penyakit adalah Si. Pengelolaan hara yang baik bertujuan untuk mendapatkan produktivitas yang tinggi dengan mempertimbangkan kemampuan lahan, potensi tanaman, dan kondisi lingkungan sehingga diperoleh produksi secara berkesinambungan.

Dengan demikian perlu dilakukan penelitian tentang pengaruh penambahan pupuk mikro dan jenis genotipe terhadap intensitas penyakit antraknosa pada tanaman sorgum (Sorghum bicolor (L.) Moench).

Tujuan penelitian ini adalah untuk mengetahui pengaruh penambahan pupuk mikro serta penggunaan beberapa genotipe sorgum terhadap intensitas penyakit antraknosa. 


\section{BAHAN DAN METODE}

Penelitian dilaksanakan dari April 2017Februari 2018 di Desa Sukanegara, Kecamatan Tanjung Bintang, Kabupaten Lampung Selatan, Provinsi Lampung dan di Laboratorium Hama dan Penyakit Tanaman Fakultas Pertanian Universitas Lampung. Perlakuan disusun menggunakan rancangan kelompok dalam rancangan petak terbagi (Split Plot Design) dimana faktor utama adalah hara mikro (dengan penambahan mikro dan tanpa penambahan mikro) dan anak petak adalah 15 genotipe sorgum (Numbu, Samurai 1, GH3, UPCA, GH4, P/I WHP, GH6, Super 2, GH13, P/F 51-93-C, Super 1, GH5, Mandau, GH 7, dan Talaga Bodas). Perlakuan ini menggunakan 30 kombinasi perlakuan yang diulang sebanyak 3 kali.

Pengolahan tanah dilakukan dua kali. Sorgum ditanam dengan jarak tanam $80 \mathrm{~cm}$ x $20 \mathrm{~cm}$. Dosis pupuk yang diaplikasikan yaitu urea sebanyak $200 \mathrm{~kg}$ ha $^{-1}$, TSP $150 \mathrm{~kg} \mathrm{ha}^{-1}, \mathrm{KCl} 200 \mathrm{~kg} \mathrm{ha}^{-1}$ dan pupuk mikro "ZincMicro" $20 \mathrm{~kg} \mathrm{ha}{ }^{-1}$. Urea dan $\mathrm{KCl}$ diaplikasikan dua kali yaitu pada saat 4 MST (1/2 dosis) dan 8 MST (1/2 dosis), sedangkan TSP dan ZincMicro diaplikasikan seluruhnya pada saat 4 MST.

Pengamatan dilakukan terhadap keterjadian penyakit serta keparahan penyakit. Nilai keterjadian penyakit dihitung menggunakan rumus sebagai berikut

$$
\mathrm{KP}=\frac{n}{N} \times 100 \%
$$

Keterangan :

$\mathrm{KP}=$ Keterjadian Penyakit

$\mathrm{n} \quad=$ Jumlah tanaman terserang

$\mathrm{N}=$ Jumlah tanaman yang diamati
Keparahan Penyakit (Disease Severity) dihitung berdasarkan pengamatan gejala penyakit pada sampel tanaman sorgum. Keparahan penyakit dihitung dengan rumus berikut (Ginting, 2013) :

$$
\mathrm{KP}=\frac{\sum n \times v}{N \times Z} \times 100 \%
$$

\section{Keterangan :}

$\mathrm{KP}=$ Keparahan Penyakit

$\mathrm{n} \quad=$ Jumlah bagian tanaman yang memiliki kategori kerusakan yang sama

$\mathrm{v}=$ Skor kerusakan dari tiap kategori serangan

$\mathrm{N}=$ Jumlah tanaman yang diamati

$\mathrm{Z} \quad=$ Skor kerusakan tertinggi

\section{HASIL DAN PEMBAHASAN}

\section{Identifikasi Penyakit Antraknosa pada Tanaman} Sorgum

Pada hasil pengamatan di lapangan ditemukan gejala penyakit antraknosa pada bagian daun yang mengalami nekrosis yang berupa bintik-bintik kecil pada daun (Gambar 1A), berbentuk lingkaran atau elips berwarna cokelat kemerahan, kemudian bintik tersebut membesar lalu menyatu sehingga daun mengalami nekrosis lanjut (Gambar 1B).

Selanjutnya pada pengamatan di laboratorium diperoleh koloni jamuryang merupakan kumpulan hifa yang terdiri dari struktur benang-benang bercabang berwarna putih (Gambar 2A) yang serupa dengan hasil isolasi biakan murni antraknosa yang didapatkan oleh Tsedaley (2016) (Gambar 2B).

Pada pengamatan secara mikroskopis ditemukan adanya struktur umum yaitu konidia jamur yang berbentuk silinder dengan ujung konidia yang sedikit meruncing (Gambar 3A). Konidia jamur yang 


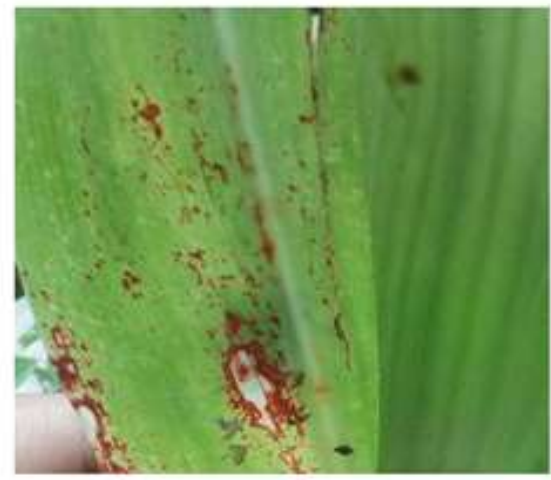

A

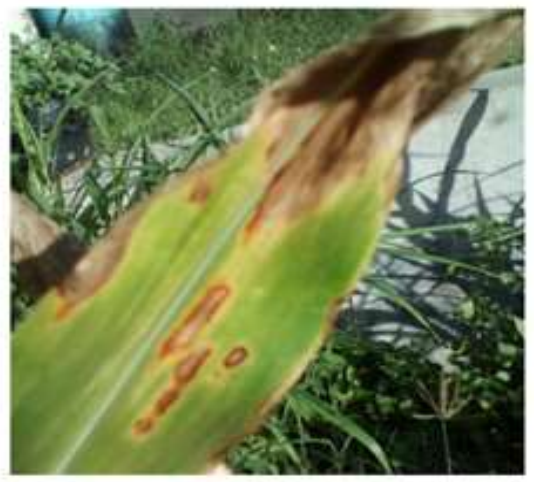

B

Gambar 1: Gejala penyakit antraknosa pada daun tanaman sorgum, yaitu muncul bintik-bintik kecil pada daun (A), bintik kemudian membesar dan menyatu sehingga daun mengalami nekrosis atau terserang $\operatorname{antraknosa}(\mathrm{B})$.

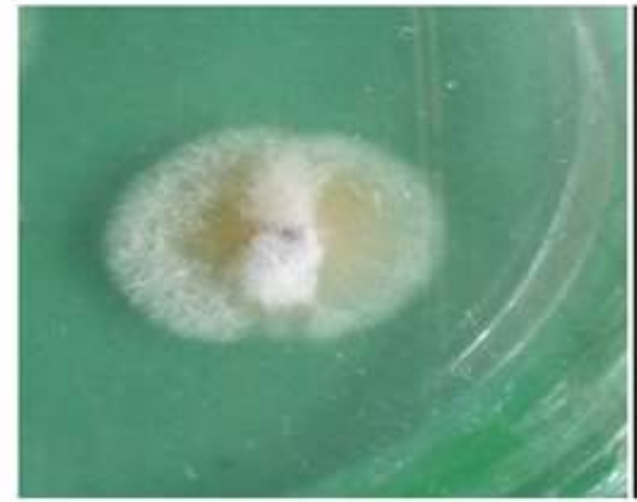

A

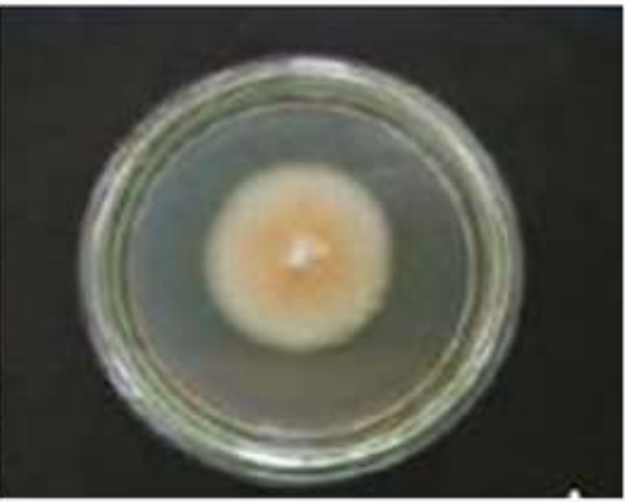

B

Gambar 2. Koloni jamur hasil isolasi (A) dan biakan murni koloni jamur antraknosa menurut Tsedaley (2016) (B) umur 7 hari.

didapatkan dari hasil isolasi tersebut serupa bentuknya yaitu berbentuk oval atau silinder menurut Frederiksen (1986) (Gambar 3B) yang mana bentuk demikian menunjukan karakteristik dari Colletotrichum sp.

\section{Pengaruh Penambahan Pupuk Mikro terhadap} Keterjadian dan Keparahan Penyakit Antraknosa pada Tanaman Sorgum.

Hasil analisis ragam menunjukkan bahwa interaksi genotipe dan pupuk mikro tidak berpengaruh terhadap intensitas penyakit antraknosa.. Perlakuan penambahan pupuk mikro tidak berpengaruh terhadap intensitas penyakit antraknosa baik pengamatan I dan pengamatan II. Namun perlakuan genotipe berpengaruh terhadap intensitas penyakit antraknosa baik pengamatan I (minggu ke-5) dan pengamatan II (minggu ke-6).

Pengaruh Genotipe terhadap Keterjadian dan Keparahan Penyakit Antraknosa pada Tanaman Sorgum.

Genotipe berpengaruh terhadap intensitas 


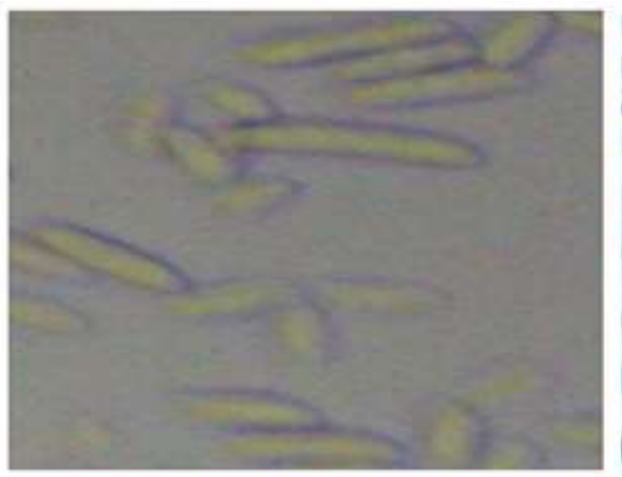

A

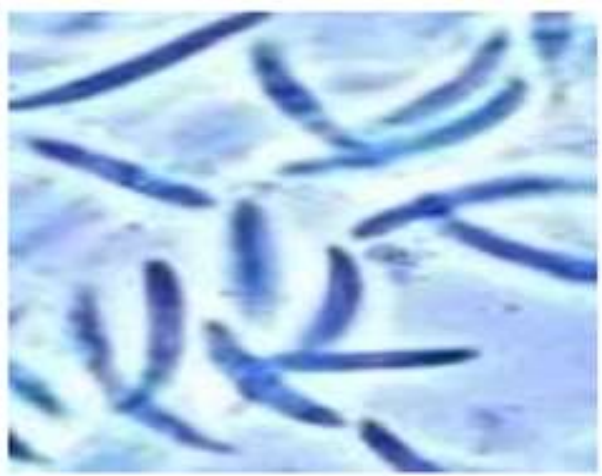

B

Gambar 3. Bentuk konidia hasil isolasi koloni jamur(A), Colletotrichum sp. menurut Frederiksen (1986)(B).

keterjadian dan keparahan penyakit antraknosa tanaman sorgum baik pengamatan I dan pengamatan II (Tabel 1).

Pada Tabel 1. dapat dilihat bahwa pengamatan I terdapat 2 genotipe yaitu Numbu dan GH 3 yang berbeda nyata dengan genotipe Super 2, sedangkan 12 genotipe yang lain tidak berbeda nyata antar satu dengan yang lainnya dalam menimbulkan keterjadian penyakit. Adapun 12 genotipe tersebut adalah Samurai , UPCA, GH 4, P/I WHP, GH 6, GH 13, P/F 5 193-C, Super 1, GH 5, Mandau, GH 7, dan Talaga Bodas.

Pada Tabel 1. dapat dilihat bahwa pengamatan II terdapat 4 genotipe yaitu genotipe Numbu, GH 3, Super, dan Talaga Bodas berbeda nyata dengan genotipe Super 2, sedangkan 10 genotipe yang lain tidak berbeda nyata antar satu dengan yang lainnya dalam menimbulkan keterjadian penyakit. Adapun 10 genotipe tersebut adalah Samurai 1, UPCA, GH 4, P/ I WHP, GH 6, GH 13, P/F 5-193-C, GH 5, Mandau, dan GH 7.

Berdasarkan Tabel 1. dapat dijelaskan bahwa pada pengamatan I genotipe Numbu, dan GH 3 memiliki intensitas keterjadian penyakit yang rendah sedangkan genotipe Super 2 memiliki intensitas keterjadian penyakit yang tinggi. Pada pengamatan II genotipe Numbu, GH3, Super 1, dan Talaga Bodas memiliki intensitas keterjadian penyakit yang rendah, sedangkan genotipe Super 2 memiliki intensitas keterjadian penyakit yang tinggi.

Pada Tabel 1. Juga dapat dilihat bahwa genotipe berpengaruh terhadap intensitas keparahan penyakit antraknosa baik pengamatan I dan pengamatan II. Pada pengamatan I genotipe GH 3 berbeda nyata dengan genotipe GH 13, sedangkan 13 genotipe yang lain tidak berbeda nyata antar satu dengan yang lainnya dalam menimbulkan keparahan penyakit. Adapun 13 genotipe tersebut adalah Numbu, Samurai , UPCA, GH 4, P/I WHP, GH 6, Super 2, P/F 5 193-C, Super 1, GH 5, Mandau, GH 7, dan Talaga Bodas.

Pada Tabel 1. dapat dilihat bahwa pada pengamatan II genotipe Super 1 berbeda nyata dengan genotipe GH 13, sedangkan 13 genotipe yang lain tidak 
Tabel 1. Pengaruh Genotipe terhadap Keterjadian dan Keparahan Penyakit

\begin{tabular}{lcccc}
\hline \multirow{2}{*}{ Perlakuan } & \multicolumn{2}{c}{ Keterjadian (\%) } & \multicolumn{2}{c}{ Keparahan (\%) } \\
\cline { 2 - 5 } & Pengamatan I & Pengamatan II & Pengamatan I & Pengamatan II \\
\hline Numbu & $16,67 \mathrm{c}$ & $21,67 \mathrm{~b}$ & $18,50 \mathrm{abcde}$ & $25,33 \mathrm{bc}$ \\
Samurai 1 & $26,67 \mathrm{abc}$ & $31,67 \mathrm{ab}$ & $20,33 \mathrm{abcde}$ & $29,00 \mathrm{abc}$ \\
GH 3 & $16,66 \mathrm{c}$ & $21,67 \mathrm{~b}$ & $13,50 \mathrm{e}$ & $24,66 \mathrm{bc}$ \\
UPCA & $41,67 \mathrm{abc}$ & $41,67 \mathrm{ab}$ & $29,66 \mathrm{abcde}$ & $36,00 \mathrm{abc}$ \\
GH 4 & $35,00 \mathrm{abc}$ & $40,00 \mathrm{ab}$ & $27,00 \mathrm{abcde}$ & $31,16 \mathrm{abc}$ \\
P/I WHP & $45,00 \mathrm{abc}$ & $51,67 \mathrm{ab}$ & $32,00 \mathrm{ab}$ & $34,83 \mathrm{abc}$ \\
GH 6 & $36,67 \mathrm{abc}$ & $41,67 \mathrm{ab}$ & $31,83 \mathrm{abc}$ & $37,00 \mathrm{ab}$ \\
GH 13 & $45,00 \mathrm{abc}$ & $50,00 \mathrm{ab}$ & $32,83 \mathrm{a}$ & $41,50 \mathrm{a}$ \\
Super 2 & $63,33 \mathrm{a}$ & $70,00 \mathrm{a}$ & $31,50 \mathrm{abcd}$ & $35,16 \mathrm{abc}$ \\
P/F 5-193-C & $60,00 \mathrm{ab}$ & $60,00 \mathrm{ab}$ & $29,00 \mathrm{abcde}$ & $34,83 \mathrm{abc}$ \\
Super 1 & $26,67 \mathrm{abc}$ & $26,67 \mathrm{~b}$ & $19,50 \mathrm{abcde}$ & $22,16 \mathrm{c}$ \\
GH 5 & $28,33 \mathrm{abc}$ & $33,33 \mathrm{ab}$ & $20,50 \mathrm{abcde}$ & $29,50 \mathrm{abc}$ \\
Mandau & $33,33 \mathrm{abc}$ & $35,00 \mathrm{ab}$ & $23,16 \mathrm{abcde}$ & $29,83 \mathrm{abc}$ \\
GH 7 & $35,00 \mathrm{abc}$ & $35,00 \mathrm{ab}$ & $26,00 \mathrm{abcde}$ & $32,16 \mathrm{abc}$ \\
Talaga Bodas & $18,33 \mathrm{bc}$ & $23,33 \mathrm{~b}$ & $15,66 \mathrm{bcde}$ & $24,33 \mathrm{bc}$ \\
\hline BNT 5\% & 41,8 & 41,3 & 16,47 & 14,29
\end{tabular}

Keterangan: Pengamatan I dilaksanakan pada minggu ke-5 sedangkan pengamatan II pada minggu ke-6. Nilai tengah pada tabel yang diikuti oleh huruf yang tidak sama berarti berbeda nyata berdasarkan uji BNT pada taraf 5\%.

berbeda nyata antar satu sama lain dalam menimbulkan keparahan penyakit. Adapun 13 genotipe tersebut adalah Numbu, Samurai 1, UPCA, GH 4, P/I WHP, GH 6, Super 2, P/F 5-193-C, GH 5, Mandau, GH 7, dan Talaga Bodas. Genotipe GH 3 pada pengamatan I dan genotipe Super 1pada pengamatan II memiliki intensitas keparahan penyakit yang rendah, sedangkan genotipe GH 13 memiliki intensitas keparahan penyakit yang tinggi pada pengamatan I dan II.

\section{Pembahasan}

Berdasarkan hasil pengamatan gejala di lapang, yang dilanjutkan dengan identifikasi dan pengamatan mikroskopis diperoleh hasil yang serupa dengan hasil penelitian mengenai penyakit antraknosa menurut
(Frederiksen, 1986). Sehingga dapat diketahui bahwa penyebab penyakit yang menyerang tanaman sorgum di Lahan Petani Tanjung Bintang Lampung Selatan adalah jamur Colletotrichum sp. penyebab penyakit antraknosa.

Terdapat beberapa faktor yang menyebabkan penambahan pupuk mikro terhadap tanaman sorgum tidak berpengaruh, salah satunya adalah lingkungan. Dalam penelitian ini lahan yang digunakan adalah lahan yang sudah pernah ditanami artinya lahan yang dipakai adalah bukan lahan yang baru, sehingga kemungkinan lahan ini telah mengandung unsur mikro yang cukup bagi tanaman jadi tidak diperlukan lagi adanya penambahan pupuk mikro. Selain itu, tanaman membutuhkan unsur hara 
mikro dalam jumlah yang sedikit sehingga jika hara mikro yang diserap tanaman berlebihan maka tidak akan menimbulkan pengaruh terhadap tanaman. Meskipun sebenarnya penggunaan pupuk mikro yaitu “ZincMicro" dapat membuat tanaman menjadi lebih kuat sehingga lebih tahan terhadap serangan penyakit (Mahmud dan Mirin, 1987).

Genotipe tanaman sorgum berpengaruh terhadap intensitas penyakit antraknosa. Beberapa genotipe sorgum yang lebih tahan terhadap penyakit antraknosa berdasarkan hasil penelitian adalah genotipe Numbu, GH 3, dan Super 1 karena memiliki nilai intensitas penyakit yang rendah dibandingkan dengan genotipe yang lainnya. Hal ini sesuai dengan hasil penelitian Yanuwar (2002) dan Soenartiningsih dan Fatmawati (2011), bahwa varietas Numbu dan Super 1 tahan terhadap penyakit antraknosa. Selain itu, menurut hasil penelitian Soenartiningsih dan Fatmawati (2011), varietas Super 1 memiliki daya adaptasi lingkungan. Menurut (Yanuwar, 2002), varietas Numbu memiliki tangkai yang kompak dan besar serta cocok ditanam pada musim kering, dan tahan terhadap hama Aphis, sedangkan untuk genotipe GH 3 sampai saat ini belum ditemukan hasil penelitian mengenai karakteristik genotipe tersebut.

Genotipe sorgum yang relatif rentan terhadap penyakit antraknosa adalah genotipe Super 2 dan GH 13 karena memiliki nilai intensitas penyakit yang tinggi dibandingkan genotipe lainnya. Menurut Nirwanto (2010), perbedaan tingkat ketahanan tanaman terhadap penyakit dikarenakan perbedaan morfologi pada masing-masing tanaman. Setiap tanaman mempunyai potensi yang berbeda secara genetik untuk mekanisme resistensi terhadap jamur, virus, bakteri, dan nematoda patogen.

\section{KESIMPULAN DAN SARAN}

\section{Kesimpulan}

Dari hasil penelitian ini dapat disimpulkan bahwa adanya perbedaan intensitas penyakit antraknosa di antara genotipe-genotipe tidak dipengaruhi oleh penambahan unsur hara mikro.

\section{Saran}

Berdasarkan penelitian yang telah dilakukan, disarankan untuk penelitian lanjut terhadap pengaruh penyakit antraknosa pada hasil produksi tanaman sorgum.

\section{UCAPAN TERIMAKASIH}

Ucapan terimakasih kepada segenap tim penelitian sorgum dan ubikayu 2017 yang telah membantu dan bekerja sama dengan baik.

\section{DAFTAR PUSTAKA}

Frederiksen, R. A. 1986. Compendium of sorghum disease. The American Phytopathological Society. St. Paul, USA. 82 p.

Ginting, C. 2013. Ilmu penyakit tumbuhan. Lembaga Penelitian Universitas Lampung. Lampung. $132 \mathrm{hlm}$.

Mahmud dan A. Mirin. 1987. Pengaruh pemupukan nitrogen dan kalium terhadap perkembangan penyakit layu fusarium pada tomat. 
Kongr.Nas. IX PF Surabaya, 15-18 Maret 1985. Surabaya. Hlm: 448-453.

Nirwanto, H. 2010. Teori dan Aplikasi Ketahanan Populasi Tanaman Terhadap Epidemi Penyakit. UPN Veteran Jawa Timur. Surabaya. $66 \mathrm{hlm}$.

Soenartiningsih dan Fatmawati. 2011. Reaksi beberapa varietas/galur terhadap penyakit utama. Prosiding Seminar Nasional Serealia Kendari, 27-28 Juli 2010. Balai Penelitian Tanaman Serealia. Kendari. Hlm: 433-437.
Suarni. 2004. Evaluasi sifat fisik dan kandungan kimia biji sorgum setelah penyosohan. Jurnal Stigma XII(1): 88-91.

Tsedaley, B., G. Adugna, and F. Lemessa. 2016. "Distribution and important of sorghum anthracnose in Southwestern and Western Ethiopia". Plant Pathology Journal 15(3): 75-85.

Yanuwar, W. 2002. "Aktivitas antioksidan dan imunomodulator serealia non- beras". Tesis. Institut Pertanian Bogor. Bogor. 